\title{
Oor die skryfwyse van Afrikaans III
}

In die vorige rubrieke oor die Afrikaanse skryfwyse het ek daarop gewys dat'n samestelling bestaan uit 'n kern (dit wat die samestelling wesenlik benoem) en 'n bepaler (wat nader besonderhede gee van dit wat die kern benoem). Die bepaler hoef nie uit net een woord ('n "stam") te bestaan nie. Die meeste woordsoorte kan die kern óf die bepaler van 'n samestelling uitmaak, maar die belangrike is dat wanneer enige woordsoort behalwe 'n byvoeglike naamwoord as bepaler optree, die kombinasie vas geskryf word. Kyk byvoorbeeld reël 14.3 van die Afrikaanse woordelys en spelreëls ${ }^{1}$ (AWS), wat'n hele reeks soorte noem.

In die tweede skryfwyserubriek het ek gewys op twee spesiale soorte samestellings waarin byvoeglike naamwoorde optree wat wel vas geskryf word, naamlik betekenisverdigting (soos by donkerkamer teenoor donker kamer) (kyk AWS, reël 14.31) en samestellende samestelling (waar die bepaler oorspronklik 'n woordgroep is: hoër onderwys), soos hoëronderwyssektor ( $A W S$, reëls 12.6, 14.26).

In hierdie aflewering kyk ons na nog twee spesiale soorte samestellings wat soms probleme oplewer, naamlik afstandsamestellings en die gewone name van plante en diere. In albei hierdie soorte speel die skryfwyse van die byvoeglike naamwoord 'n rol.

In die geval van samestellende samestelling tree'n kombinasie wat gewoonlik los geskryf word, gesamentlik as bepaler van 'n volgende selfstandige naamwoord op: (hoër onderwys) + sektor $=$ hoëronderwyssektor of (eerste minister $)+$ woning $=$ eersteministerswoning.

By afstandsamestellings ( $A W S$, reëls 12.24 en 12.25) staan die gewoonlik los geskrewe woordgroep egter laaste, byvoorbeeld massa $+($ hoër onderwys $)=$ massa- hoër onderwys. Let op die koppelteken en spasie ná massa.

By herhaling: Die verstekreël is dat wanneer 'n byvoeglike naamwoord (b.nw.) 'n selfstandige naamwoord (s.nw.) bepaal, die twee los van mekaar geskryf word. Van nature, by wyse van spreke, is dit dus b.nw. + s.nw. = hoër onderwys. As 'n s.nw. egter'n ander s.nw. bepaal (of "beskryf"), word die twee vas aan mekaar geskryf, dus s.nw. + s.nw. = massaonderwys.

Maar nou werk dit nie altyd net so eenvoudig nie. Omdat 'n mens onderwys in massaonderwys wil presiseer, kan jy as 't ware die samestelling van s.nw. + s.nw. splyt deur 'n b.nw. in te voeg: massa (s.nw.) + hoër (b.nw.) + onderwys (s.nw.). Die manier waarop die Afrikaanse spelreëls dié probleem oplos, is om 'n sg. afstandsamestelling te skep deur 'n koppelteken direk ná die eerste s.nw. te plaas, gevolg deur 'n spasie. Presies wat die bedinkers van dié soort samestelling in gedagte gehad het toe hulle dié oplossing bedink het, is nie seker nie, maar 'n mens kan op twee maniere daarna kyk: eerstens dat die sg. afstandskoppelteken die eerste s.nw. (hier massa) as 't ware bo-oor die tussenkomende b.nw. (hoër) verbind met die tweede s.nw. (onderwys). Die tweede manier van kyk is om te dink dat die afstandskoppelteken die eerste s.nw. verbind met 'n woordgroep of woordpaar, nl. 'n soos gewoonlik los geskrewe kombinasie van b.nw. + s.nw.

\footnotetext{
Verwysings is na die 10de uitgawe van die $A W S$ (2009).
} 
Nog voorbeelde is derdejaar-mediese student, adjunk- besturende direkteur, hoëspoedelektriese waaier, top-akademiese presteerder, stads-siviele ingenieur, reuse-politieke saamtrek.

Die skryfwyse van die gewone name (wat in Engels die "common names" genoem word) van plante en diere is iets wat oor 'n lang tydperk ontstaan het; dit is dus nie iets waaroor 'n Taalkommissie die een of ander tyd in die verlede sommer besluit het nie. Die reëls daaroor in die $A W S$ is uit die gevestigde gebruik afgelei ( $A W S$, reëls 9.7, 14.29). Ek beperk my hier bloot tot die name waarvan 'n b.nw. deel is.

Die probleem wat sulke name betref, is dat baie b.nwe. vas aan die s.nw. geskryf word en ander weer los, en dis nie altyd duidelik watter los geskryf word nie. Wat met 'n redelike mate van sekerheid gesê kan word, is dat onverboë b.nwe., met inbegrip van gewone kleuraanduidende b.nwe., vas geskryf word, en dat b.nwe. wat van eiename (veral geografiese name) afgelei is, los geskryf word. Tussenin is daar egter 'n klompie "gewone" b.nwe. wat ook los geskryf word.

Die maklikste is seker om 'n klompie voorbeelde te noem wat bostaande illustreer:

\begin{tabular}{|c|c|c|c|}
\hline \multicolumn{2}{|c|}{ b.nw. vas } & \multirow{2}{*}{$\begin{array}{c}\begin{array}{c}\text { eienaam-afgeleide } \\
\text { b.nw. los }\end{array} \\
\text { Abessynse ibeks }\end{array}$} & \multirow{2}{*}{\begin{tabular}{|c|}
$\begin{array}{c}\text { "gewone" } \\
\text { b.nw. los }\end{array}$ \\
bebaarde witviooltjie
\end{tabular}} \\
\hline bitteraalwyn & ligblousalie & & \\
\hline bleekvleivalk & mooinooientjie & Afrikaanse olifant & bloeiende hartjie \\
\hline blinkblaar & oranjetjiekerientjee & Afrikaanse seder & doringrige blaasop \\
\hline blouwalvis & ouhout & Amerikaanse boa & gekolde vylvis \\
\hline bontpaling & platanna & Arabiese kameel & gemantelde brulaap \\
\hline bruinvaalboom & rooiels & $\begin{array}{l}\text { Barbertonse } \\
\text { madeliefie }\end{array}$ & gevlekte hiëna \\
\hline dikkop & silwerjakkals & Chinese aster & gewone naboom \\
\hline doodkruid & skurwejantjie & Egiptiese kobra & harige kanniedood \\
\hline gladdesuurpruim & skurweklipels & Italiaanse raaigras & heilige lotus \\
\hline goudlelie & smalblaar & Japanse blomkweper & noordelike malgas \\
\hline gouesipres & soetdoring & Kaapse kreef & tropiese grysbok \\
\hline groendoring & stinkhout & Namibiese taaibos & westelike geelhout \\
\hline groenmamba & suurkaree & Noorweegse spar & wollerige broodboom \\
\hline grootalbatros & swartwitpens & Oos-Kaapse hardepeer & \\
\hline grootwithaai & taaibos & & \\
\hline hardepeer & vaalbos & & \\
\hline kleinrooivalk & valsmaroela & & \\
\hline langtoon & wildehond & & \\
\hline
\end{tabular}


'n Paar dinge word uit bostaande voorbeelde duidelik:

(i) B.nwe. van alle kleure en geure, en selfs meer as een op 'n slag, kan in die gewone name van plante en diere optree.

(ii) Sulke b.nwe.word meestal vas geskryf, selfs as daar meer as een in die naam is.

(iii) Die b.nwe. in (ii) bedoel, kan verboë of onverboë wees.

(iv) Die b.nwe. wat van eiename afgelei word, word los geskryf (en is nie problematies nie).

(v) Die "gewone" b.nwe. wat los geskryf word, is dikwels byvoeglik gebruikte deelwoorde (soos bebaarde), maar glad nie altyd nie, en is altyd verboë.

Dit is nie moontlik om die skryfwyse van b.nwe. wat deel van die gewone name van plante en diere is, probleemloos te bereël nie. Gebruikers word aangeraai om in twyfelgevalle 'n betroubare bron te raadpleeg.

Lesers wat nie 'n $A W S$ besit nie, word aangemoedig om hierdie belangrike Akademiepublikasie aan te skaf. Dit sal Afrikaansskrywendes beslis baat om die Spelreëls-afdeling daarvan minstens aandagtig deur te blaai sodat hulle kan kennis neem van wat daarin bereël word, en dan is die Woordelys- en die Afkortingslys-afdeling natuurlik nuttige kitsnaslaanbronne. Die $A W S$ is heel toeganklik via die inhoudsopgawe, die indeks agterin, interne kruisverwysings, 'n termlys, en so meer.

En vanjaar verskyn 'n eeufeesuitgawe van hierdie onmisbare skryfhulp!

JD (ToM) McLachlan

Vertaler en Taalversorger

E-pos: tommcl@whalemail.co.za 